\title{
An Inquiry into Saudi EFL Teachers and Students' Perceptions of EFL Virtual Classes and Its Relation to Learner Autonomy
}

\author{
Abrar Khalawi \\ Dept. of English Language Institute, King Abdulaziz University \\ King Abdulaziz University, P.O. Box 42801, Jeddah 21551, Saudi Arabia \\ Dr. Maha Halabi (Corresponding author) \\ Dept. of English Language Institute, King Abdulaziz University \\ King Abdulaziz University, P.O. Box 42801, Jeddah 21551, Saudi Arabia
}

Received: April 29, 2020 Accepted: May 18, 2020 Published: May 20, 2020

doi:10.5296/ijele.v8i2.17065 URL: https://doi.org/10.5296/ijele.v8i2.17065

\begin{abstract}
The purpose of this research paper is to explore Saudi foundation-year teachers and students' perceptions of the use of virtual classes for teaching or learning English as a Foreign Language (EFL) at the English Language Institute (ELI) in King Abdulaziz University (KAU). The data for this study was collected through questionnaires from a total of 20 teachers and 22 students. The survey was conducted during the second semester of the academic year 2019-2020, and the data was analyzed quantitatively. The overall results of the questionnaires demonstrate that the majority of teachers and students held positive attitudes towards EFL virtual classes, however, they prefer face-to-face classrooms. Additionally, some participants admitted the huge role virtual classes play in improving learners' autonomy.
\end{abstract}

Keywords: EFL, EFL virtual classes, perceptions, autonomy, autonomous learning 


\section{Introduction}

Advancements in technology and internet usage continue to increase the techniques that can be used for teaching and learning. E-learning and virtual classes have been a popular educational tool aimed at enhancing the effectiveness and efficiency of the educational process. Thus, this paper seeks to achieve two objectives.

\subsection{Aims and Objectives}

Firstly, to find out the perceptions of students and teachers towards the use of virtual classes in the study of English as a Foreign Language (EFL). Secondly, to examine the relation of virtual classes and learner autonomy. The study attempts to answer the following questions.

\subsection{Research Questions}

1. How do foundation-year EFL teachers and students in Saudi Arabia perceive virtual classes?

2. Does utilising virtual classes for EFL teaching and learning enhance learner autonomy, according to the participants' experience?

\subsection{Research Problem}

Despite the vast advancements that have been noticed in the field of technology and learning, virtual classes have not been widely acknowledged nor practiced by the majority of teachers and students at King Abdulaziz University (KAU). However, due to the unforeseen circumstances that the Coronavirus (Covid-19) have caused during the second semester of the academic year 2019-2020, the university have decided to close its doors and utilise virtual classes with all its sectors for the safety of teachers and students. Virtual classes were set to be implemented using Blackboard which is a web-based virtual learning software. For many teachers and students, learning or teaching through virtual classes was a new experience which they had to deal with, thus, their perceptions on this experience was set as one of the objectives of this study. Moreover, the second objective is to explore the relation between EFL virtual classes and learner autonomy since little research has been done on the effect of these classes on learners' autonomy in Saudi Arabia.

\section{Literature Review}

\subsection{Learner Autonomy}

The concept of autonomy within language learning is defined as an individual's capacity to take responsibility for their own learning process (Holec, 1981). An autonomous learner assumes the responsibility for establishing the content, purpose and method of their learning process; following the progress of the process and eventually evaluating the outcomes (Holec, 1981). According to Benson (2003), the autonomy of learners is comprised of two key elements, their willingness and ability to make independent choices. All these definitions highlight what an autonomous learner can do as opposed to how they are able to do it. A focus on how a learner can achieve autonomy introduces concepts such as teaching methodology, learner training, and teacher involvement. Virtual classes and e-learning are a teaching mode that is associated with learner autonomy, giving the learner the freedom of 
control, desire and ability to regulate their learning process.

For the sake of this paper, learner autonomy is considered an individual and collective capacity that is fueled through a social interactive process. This is the process relied upon by the students and teachers of English as a Foreign Language for effective cooperation (Misir, Koc, \& Koc, 2018). The concept of learner autonomy is therefore used as the foundational background within this literature review.

\subsection{EFL Teachers and Students' Perceptions on Virtual Learning Classrooms}

Al-Qahtani (2019) conducted a study on fifteen students and fifteen teachers to elicit their perceptions on the experience of using virtual classes for the learning and teaching of EFL. 57 percent of the student respondents reported a positive experience with virtual classes with 43 percent indicating that they preferred face to face classes. Among the widely cited advantages of virtual classes by students included a creation of a comfortable learning convenient environment that often saved time and effort and the ability to record a class through the recording feature that could be replayed whenever it was required. However, key disadvantages were also highlighted including technical problems, internet problems and the lack of body language and facial expressions between the teachers and learners. In the same study, 62 percent of the teacher respondents reported a positive experience with teaching EFL using virtual classes while 38 percent reported a negative experience. The main advantages cited by the teachers included the opportunity to use sensory-rich environments that motivate the students, enhanced convenience and time management as well as the ability to share information that can be accessed by any student or teacher at any time. However, the teachers reported technical problems, the requirement for extra training, challenges with checking a student's comprehension that would necessitate blending of the teaching methods. This implies that it is not enough to use virtual classes on their own for EFL teaching as not all aspects of the teaching can be evaluated and taught effectively such as comprehension.

These results are supported by an earlier study on the perceptions of EFL students on student-student interactions and student-instructor interactions in virtual classes. In the study, 52 respondents are used, 49 EFL students and 3 instructors (Alamir, 2015). To begin with, the mean value for the perceptions of the students was reported as high for instructor-student interactions as opposed to student-student interactions within the virtual class. This implies that the students liked more their interactions with their instructors through the online platform as compared to their interaction with their fellow peers. This was attributed to the benefit of instructor student interactions when compared to student-student interactions with the students confirming that interacting with their instructors contributed towards the development of their English language and the learning of new lexical forms. In addition, high means were reported by the students in response to the statement that their online interactions with the instructors were beneficial within their journey of learning language. This implies that most of the students considered their instructors as being valuable, deeming their online interactions as positive. 88 percent of the student respondents reported valuing the online interactions between them and the instructors, influencing them to pay more attention to the lessons and strive to improve their language. 


\section{Mll Macrothink}

International Journal of English Language Education

ISSN 2325-0887

2020, Vol. 8, No. 2

In another study by Alamir (2016), identifies instructors as a critical prerequisite in the promotion of students' learning within an online environment. In the study, the instructors exhibit varying rates of social presence, participation and discourse functions when interacting with the students. All these differences are however critical in supporting the learning of the student, necessitating the continued commitment of instructors within a virtual class for EFL. This is supported by Solak \& Cakir (2014) in whose study the academic achievement of students using e-learning was comparatively higher than those for students learning through face to face. However, there was no significant difference in the view of different students (whether online, blended or face to face class students) on learning EFL through virtual classes as all students expressed support for e-learning especially in relation to its ability to allow for self-expression from the students and the support and quality of interaction enjoyed from the instructors using this mode of teaching.

Online games are also established to have a significant influence on the grammar performance of EFL students (Hakami \& Abdelrahman, 2019). In this study, it is reported that games lower student stress, create motivation and provide an opportunity for the learners to engage in real communication. The study therefore reported improvements in online EFL student performances attributed to the use of games within their virtual classes.

Developments in the field of teaching and learning have witnessed the incorporation of e-learning as a teaching mode. From the literature review, it is evident that both the students and teachers' perception of the use of virtual classes for EFL is positive, indicating that both parties are open and in support of the use of virtual classes. Thus, this paper aims to find out if EFL foundation-year teachers and students at King Abdulaziz University in Jeddah, Saudi Arabia share the same views or not.

\section{Methodology}

In an attempt to explore the perceptions of foundation-year Saudi teachers and students of EFL virtual classes at the English Language Institute (ELI) in King Abdulaziz University (KAU), this quantitative study examined teachers and students' views on virtual classes and its relation to learner autonomy. The study included a quantitative approach of data collection with a few open-ended questions to obtain a comprehensive understanding of the proposed research questions.

\subsection{Research Design}

\subsubsection{Participants}

The targeted population of this study were 20 EFL teachers and 22 foundation-year students studying EFL, all of whom were Saudi females who experienced EFL virtual classes at the ELI in KAU in Jeddah, Saudi Arabia. The age of most teachers $(70 \%, n=14)$ ranged from 30 to 49 years old, and the age range of most students $(86.4 \%, n=19)$ was from 18 to 22 years old.

\subsubsection{Instruments of Data Collection}




\section{MlMacrothink}

To collect the data required to address the research questions, two questionnaires of 12 questions each were adapted from Al-Qahtani's (2019) research on teachers and students' perceptions of EFL virtual classes. Both questionnaires were the same except for replacing the word "teaching" for "learning" in the student questionnaire. Some changes were made on the questionnaires by the researcher. The first two questions elicited general and demographic information on participants. The following five questions sought to examine teachers and students' views on EFL virtual classes to answer the first research question. The next four questions investigated the relation of EFL virtual classes on learner autonomy. Finally, the last question aimed to list the advantages and disadvantages of EFL virtual classes.

\subsubsection{Procedure}

The instruments of the study were administrated during the second half of the second semester of the academic year 2019-2020 at the ELI in KAU. The questionnaire was created using Google Forms and sent to a group of teachers and their students. The results were analysed quantitively.

\subsubsection{Time Plan}

Table 1. Time plan table

\begin{tabular}{|l|l|}
\hline Category & Amount of time needed \\
\hline Data collection & One week \\
\hline Data analysis & One week \\
\hline Writing up results & Two weeks \\
\hline Editing dissertation & Three days \\
\hline
\end{tabular}

The total time needed to conduct the study was four weeks and three days. On the first week, that there was collected using Google Forms and on the following week the data was analyzed and organized in tables and figures. The last two weeks were for writing up the results and discussion and editing the paper.

\section{Results}

The questionnaires in the study seek to investigate both participant teachers' and students' views on teaching or learning EFL through virtual classes and its relation to learner autonomy. Thus, the results are divided into two sections and each section is sub-divided into two parts. The first section discusses: (a) teachers' perceptions on teaching EFL through virtual classes, and (b) teachers' viewpoint on the effect of EFL virtual classes on learner autonomy. The second section examines: (a) students' perceptions on learning EFL through virtual classes, and (b) students' viewpoint on the effect of EFL virtual classes on learner autonomy.

\subsection{Teachers' Perceptions}

\subsubsection{Teachers' Perceptions on Teaching EFL through Virtual Classes}


Teachers' attitude towards EFL virtual classes

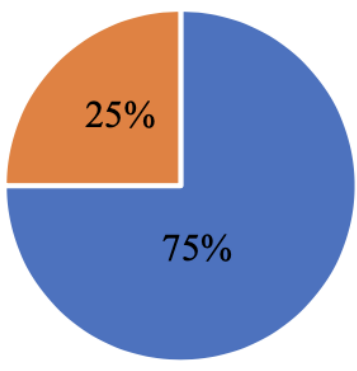

- Positive attitdue

- Negative attitiude

Figure 1. Teachers' attitude towards EFL virtual classes

\section{Do teachers prefer using a virtual class in their} teaching rather than a face-to-face classroom setting?

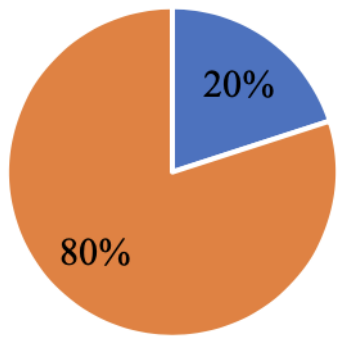

- Yes

- No

Figure 2. Teachers' views towards EFL virtual classes

Table 2. Teachers' opinions on the advantages and disadvantages of EFL Virtual classes

\begin{tabular}{|c|c|c|}
\hline Item & Advantages & Disadvantages \\
\hline \multirow[t]{3}{*}{$\begin{array}{l}\text { What are the advantages and } \\
\text { disadvantages of virtual } \\
\text { classes? }\end{array}$} & $\begin{array}{c}\text { "Easy to access from } \\
\text { anywhere and at anytime" }\end{array}$ & $\begin{array}{c}\text { "Lack of participation and } \\
\text { students' unwillingness to } \\
\text { speak" }\end{array}$ \\
\hline & $\begin{array}{l}\text { "Provides a comfortable } \\
\text { environment" }\end{array}$ & $\begin{array}{c}\text { "Unsure if learners are paying } \\
\text { attention or not" }\end{array}$ \\
\hline & $\begin{array}{l}\text { "Ability to share any } \\
\text { multimedia content with } \\
\text { students which could be } \\
\text { really engaging" }\end{array}$ & $\begin{array}{l}\text { "Difficult to conduct when } \\
\text { there are technical or internet } \\
\text { issues" }\end{array}$ \\
\hline
\end{tabular}




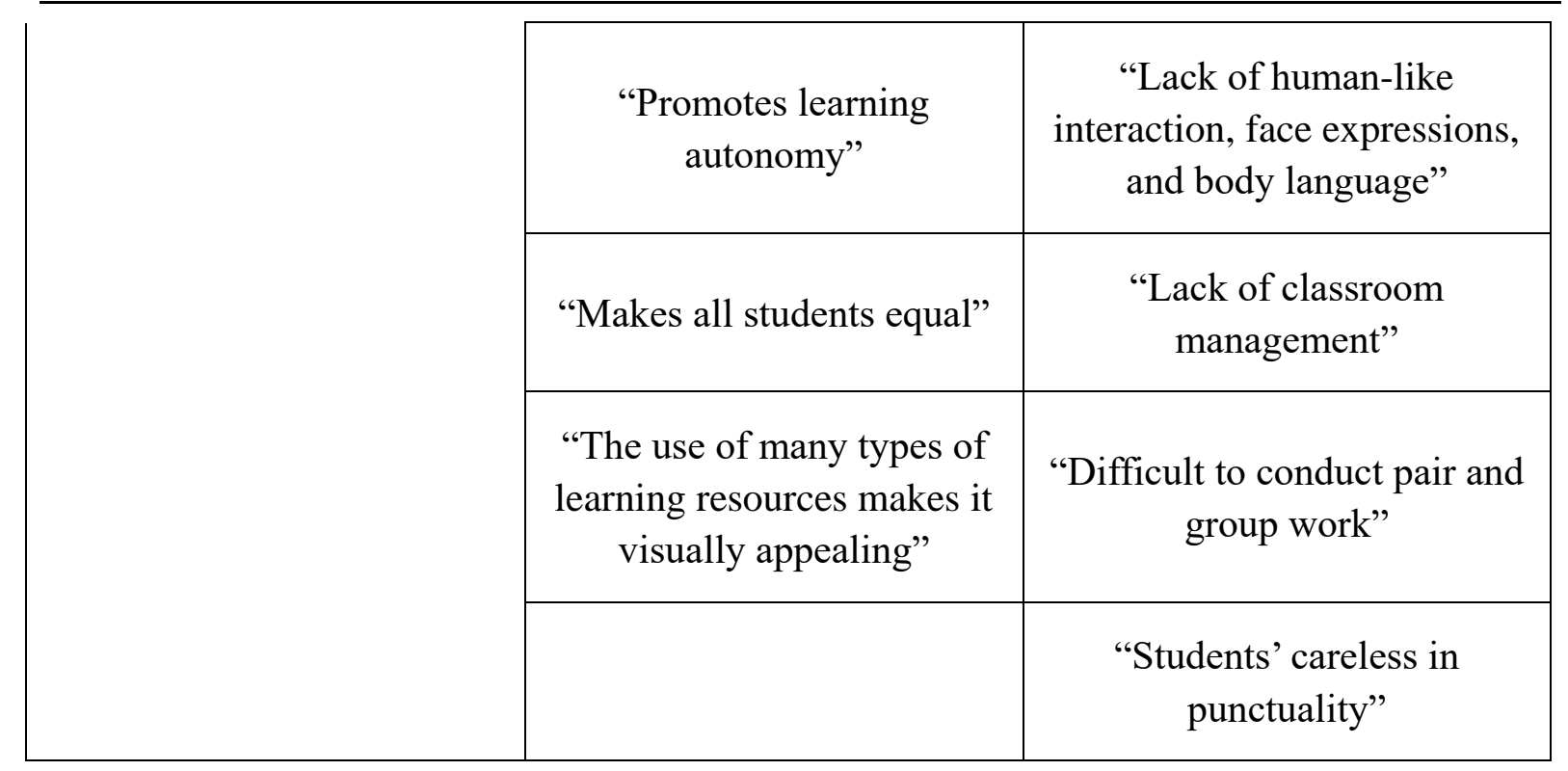

As seen in Figure 1, the responses of the majority of teachers $(75 \%, n=15)$ demonstrated that they had positive attitudes towards virtual classes. However, as shown in Figure 2, most of the teachers $(80 \%, n=16)$ prefer teaching face-to-face classrooms rather than virtual classes. Table 2 illustrates the responses of the teachers regarding the EFL virtual classes' advantages and disadvantages.

\subsubsection{Teachers' Viewpoint on the Effect of EFL Virtual Classes on Learner Autonomy}

Table 3. Teachers' opinions on the role of EFL virtual classes on learner autonomy

\begin{tabular}{|l|c|c|}
\hline Item & Agree & Disagree \\
\hline $\begin{array}{l}\text { 1) "Virtual classes promote responsibility, self-awareness, and } \\
\text { self-dependence". }\end{array}$ & $35 \%$ & $65 \%$ \\
\hline $\begin{array}{l}\text { 2) Do you believe that it is possible that learners develop the four } \\
\text { EFL skills autonomously via virtual classes? }\end{array}$ & $30 \%$ & $70 \%$ \\
\hline $\begin{array}{l}\text { 3) Do virtual classes play a significant role in making learners } \\
\text { autonomous? }\end{array}$ & $40 \%$ & $60 \%$ \\
\hline
\end{tabular}

Table 4. Teachers' opinions on the role of EFL virtual classes on learner autonomy

\begin{tabular}{|l|c|c|}
\hline Item & Teachers' data & Contrary views \\
\hline $\begin{array}{l}\text { 4) How do virtual classes } \\
\text { make learners } \\
\text { autonomous? }\end{array}$ & $\begin{array}{c}\text { It gives them confidence } \\
\text { which leads to autonomous } \\
\text { learning. }\end{array}$ & $\begin{array}{c}\text { It does not make learners } \\
\text { autonomous. }\end{array}$ \\
\cline { 2 - 3 } & $\begin{array}{c}\text { It enables students to look } \\
\text { and search for more } \\
\text { information or extra } \\
\text { explanation online. }\end{array}$ & \\
& & \\
& & \\
\end{tabular}




\begin{tabular}{|c|c|c|}
\hline $\begin{array}{c}\text { It encourages them to be } \\
\text { fully aware of the } \\
\text { importance of activating } \\
\text { their roles in the learning } \\
\text { process. }\end{array}$ & \\
\hline $\begin{array}{c}\text { It gives students the } \\
\text { independence of attending } \\
\text { the class with no force. }\end{array}$ & \\
\hline
\end{tabular}

On the teacher questionnaire, there were four items that elicited teachers' responses on the role virtual classes play on learners' autonomy. Their answers regarding three items are explained as shown in Table 3, and their responses to the open-ended question are shown in Table 4. Some of the participant teachers have provided examples of how virtual classes can support learners' autonomy. However, others $(60 \%, n=12)$ disagree that these kinds of classes have an impact on learners' autonomy.

\subsection{Students'Perceptions}

\subsubsection{Students' Perceptions on Teaching EFL through Virtual Classes}

Students' views towards EFL virtual classes

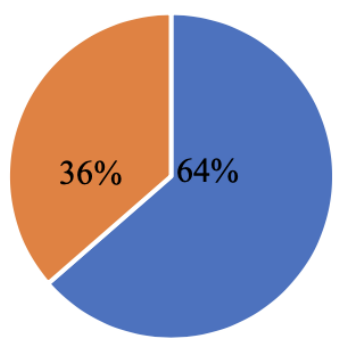

- Positive attitdue

- Negative attitiude

Figure 3. Students' attitude towards EFL virtual classes

Do you prefer using a virtual class in learning EFL rather than a face-to-face classroom setting?

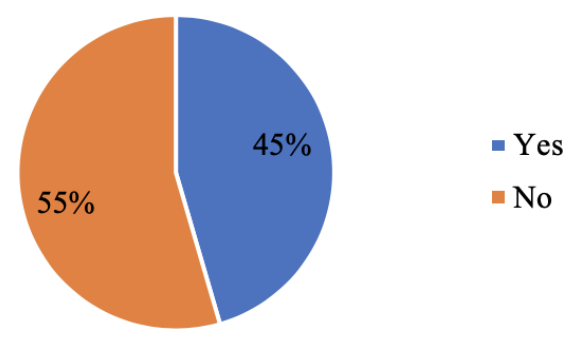

Figure 4. Student's views towards EFL virtual classes 


\section{Macrothink}

Table 5. Students' opinions on the advantages and disadvantages of EFL Virtual classes

\begin{tabular}{|c|c|c|}
\hline Item & Advantages & Disadvantages \\
\hline \multirow[t]{5}{*}{$\begin{array}{l}\text { What are the advantages and } \\
\text { disadvantages of virtual } \\
\text { classes? }\end{array}$} & $\begin{array}{l}\text { "Students can participate } \\
\text { with confidence" }\end{array}$ & $\begin{array}{l}\text { "It's difficult to learn EFL } \\
\text { online, I understand better in } \\
\text { face-to-face lectures" }\end{array}$ \\
\hline & $\begin{array}{c}\text { "Helps students depend on } \\
\text { themselves and participate } \\
\text { without being shy" }\end{array}$ & $\begin{array}{l}\text { "Some students don't have } \\
\text { laptops or internet } \\
\text { connection" }\end{array}$ \\
\hline & $\begin{array}{l}\text { "Students have more } \\
\text { opportunities" }\end{array}$ & $\begin{array}{c}\text { "Inability to reach and ask the } \\
\text { teacher to correct my } \\
\text { mistakes" }\end{array}$ \\
\hline & "Visually appealing" & $\begin{array}{l}\text { "Doesn't work large number } \\
\text { of students" }\end{array}$ \\
\hline & $\begin{array}{l}\text { "Easy to attend from } \\
\text { anywhere at any time and } \\
\text { easy to access since I don't } \\
\text { have to struggle with } \\
\text { transportation" }\end{array}$ & \\
\hline
\end{tabular}

As shown in Figure 3, $(64 \%, n=14)$ of the respondent students indicated that they held positive attitudes towards virtual classes. However, as seen in Figure 2, almost half of the participant students $(55 \%, n=12)$ prefer learning EFL in face-to-face classrooms rather than through virtual classes. Table 5 illustrates the responses of the students regarding the EFL virtual classes' advantages and disadvantages.

\subsubsection{Students' Viewpoint on the Effect of EFL Virtual Classes on Learner Autonomy}

Table 6. Students' opinions on the role of EFL virtual classes on learner autonomy

\begin{tabular}{|l|c|c|}
\hline Item & Agree & Disagree \\
\hline $\begin{array}{l}\text { 1) "Virtual classes promote responsibility, self-awareness, and } \\
\text { self-dependence". }\end{array}$ & $77.3 \%$ & $22.7 \%$ \\
\hline $\begin{array}{l}\text { 2) Do you believe that it is possible to develop the four EFL skills } \\
\text { autonomously via virtual classes? }\end{array}$ & $54.5 \%$ & $45.5 \%$ \\
\hline $\begin{array}{l}\text { 3) Do virtual classes play a significant role in making you an } \\
\text { autonomous learner? }\end{array}$ & $54.5 \%$ & $45.5 \%$ \\
\hline
\end{tabular}


Table 7. Students' opinions on the role of EFL virtual classes on learner autonomy

\begin{tabular}{|l|c|c|}
\hline Item & Students' data & Contrary views \\
\hline $\begin{array}{l}\text { 4) How do virtual classes } \\
\text { learner? an autonomous }\end{array}$ & $\begin{array}{c}\text { "I can count on myself to } \\
\text { attend the lecture and look } \\
\text { for new information" }\end{array}$ & $\begin{array}{c}\text { "It does not help me become an } \\
\text { autonomous learner" }\end{array}$ \\
\cline { 2 - 3 } & $\begin{array}{c}\text { "It boosts my confidence" } \\
\text { "I am in control of my } \\
\text { learning process" }\end{array}$ & \\
& $\begin{array}{c}\text { "It promotes } \\
\text { self-dependence in which } \\
\text { we take more } \\
\text { responsibilities of our } \\
\text { learning process and } \\
\text { improvement" }\end{array}$ & \\
\cline { 2 - 3 } & $\begin{array}{c}\text { "It improved my technology } \\
\text { knowledge and made me } \\
\text { create different solutions to } \\
\text { get my assignments done" }\end{array}$ & \\
\hline
\end{tabular}

The students' questionnaire had four items that sought to obtain students' responses on the role virtual classes play in making them autonomous learners. Their responses to three of the questions are displayed in Table 6, and their answers to the open-ended question is shown in Table 7. Some of the respondent students gave examples of how EFL virtual classes help them become autonomous learners. On the other hand, $(45.5 \%, n=10)$ disapproved that virtual classes made them autonomous learners.

\section{Discussion}

5.1 RQ1: How do foundation-year EFL teachers and students in Saudi Arabia perceive virtual classes?

The data from both questionnaires demonstrated that the participating Saudi EFL teachers and students at the ELI in KAU had positive attitudes towards EFL virtual classes, nonetheless, the greater part of the participants favored face-to-face classroom setting due to the many complications that accompany virtual learning. These findings partially contradict the findings of other studies (Al-Qahtani, 2019; Alamir, 2015) who found that teachers and students have positive perceptions of EFL virtual classes and that the majority of them prefer 
using virtual classes rather than face-to-face classes. A possible explanation for these findings may be that the participants of this study are not used to virtual classes, teachers may not be well-trained, students might not be taking virtual classes seriously, and maybe because the website is new and keeps updating and changing. Thus, these complications could be fixed by providing training courses for the teachers, giving students weekly virtual classes to get them used to it and assign grades for attending and participating in order for them to take it more seriously.

Moreover, albeit most participant teachers and students in the study did not favor virtual classes, they have mentioned many advantages of it. Among the widely cited advantages of virtual classes by both teachers and students included the ability to use multimedia resources which is engaging and visually appealing, the flexibility it provides to attend from anywhere at any time, and the equal chances it offers to all students; all of which confirm the results of Al-Qahtani (2019) regarding the advantages mentioned by the participants. The respondents also mentioned some of the disadvantages of virtual learning that are in line with (Al-Qahtani, 2019; Alamir 2015), for instance: internet and technical issues, lack of body language and face expressions, inability to conduct pair and group work, and students' carelessness of punctuality.

\subsection{RQ2: Does utilising virtual classes for EFL teaching and learning enhance learner} autonomy, according to the participants' experience?

The second research question sought to explore the impact of EFL virtual classes on enhancing learners' autonomy. The survey had four items to elicit how these classes can promote and enhance learner autonomy from the participants' own experiences. The first item asked participants about their beliefs about EFL virtual classes' role in promoting responsibility, self-awareness, and self-dependence; the majority of the participant teachers did not agree with the statement, however, most of the participant students believed that virtual classes help them take more responsibilities and depend more on themselves as learners. The second item questioned virtual classes' probability in developing learners' EFL skills autonomously, and the findings showed that more than half of the students agree that they can develop the four skills of EFL independently through virtual classes, whereas only $(30 \%, n=6)$ of teachers agree to that. As for the last two items which examined participants' own reflections on the impact of virtual classes in developing learner autonomy, more than half of the students asserted that this type of classes actually play a significant role in promoting the independent learning process, while only $(40 \%, n=8)$ of teachers conceived that it did; especially in the following aspects: looking or creating new ways to gain new information independently, boosting confidence in oneself, controlling the learning process and taking more responsibility.

\section{Conclusion}

This study found that although most Saudi EFL teachers and students had positive attitudes towards the use of virtual classes for teaching or learning EFL, some of them actually 
preferred face-to-face classes due to the various issues that they encounter when using virtual classes, such as technical and connection issues. Moreover, the majority of teachers do not believe that EFL virtual classes promote learners' autonomy, however, a higher percentage of the participant students affirmed that it helped them to be autonomous learners in many ways, like: looking for new information in different resources by themselves, taking responsibility of their own learning process, and promoting self-independence. Finally, although the volunteered participants in this study were highly qualified, the findings are limited because of the small sample. I recommend conducting the same study with a larger group of teachers and students from different schools and institutions to obtain more generalizable findings.

\section{Acknowledgement}

I would like to express my gratitude to my supervisor, Dr. Maha Halabi, who guided me throughout this project. I would also like to thank the participant teachers and students who offered deep insights into this study.

\section{References}

Alamir, A. H. (2015). Saudi EFL Students' perceptions toward the Onlin Interactions of their Peers and Instructors. Arab World English Journal (AWEJ), 6(3), 166-190. http://dx.doi.org/10.2139/ssrn.2834735

Alamir, A. H. (2016). Exploring the Interactions and Perceptions of EFL Instructors in the Saudi Online Learning Environment. Arab World English Journal (AWEJ), 7(1), 160-177. http://dx.doi.org/10.2139/ssrn.2804004

Al-Qahtani, M. H. (2019). Teachers' and Students' Perceptions of Virtual Classes and the effectiveness of Virtual Classes in enhancing Communication Skills. Arab World English Journal, Special Issue: The Dynamics of EFL in Saudi Arabia, 223-240. https://doi.org/10.24093/awej/efl1.16

Benson, P. (2003). Learner autonomy in the classroom. In D. Nunan, Practical English Language Teaching (pp. 289-308). New York: McGraw-Hill.

Hakami, H. A., \& Abdelrahman, A. B. (2019). The effects of using games in teaching and learning English Grammar to EFL learners. Journal of Educational and Psychological Sciences, 3(26), 147-159. https://doi.org/10.26389/AJSRP.H080719

Holec, H. (1981). Autonomy and foreign language learning. Oxford: Pergamon Press.

Misir, H., Koc, D. K., \& Koc, S. E. (2018). An Analysis of Learner Autonomy and Autonomous Learning Practices in Massive Open Online Language Courses. Arab World English Journal(4), 24-39. http://dx.doi.org/10.2139/ssrn.3226679

Solak, E., \& Cakir, R. (2014). Face to Face or E-Learning in Turkish EFL Context. Turkish Online Journal of Distance Education (TOJDE), 15(3). https://doi.org/10.17718/tojde.43750 


\section{Appendix}

Appendix 1. Students' Questionnaire

A questionnaire regarding Students' Reflections on Their Experiences with EFL Virtual Classes.

\section{General information:}

- Age:

$$
18-20 / 20-22 / 22-25 / 25+
$$

- Section:

Arts track / Science track

\section{Students' perceptions:}

1. Do you prefer using a virtual class in your learning rather than a face-to-face classroom setting?

Yes No

2. What kind of attitudes do you have towards virtual classes?

Positive attitudes / Negative attitudes

3. Do you think that using a virtual class can cause difficulties or problems that may handicap your learning process?

Yes No

4. If Yes, list the major difficulties you have encountered?

5. Rate your opinion of the statement "Virtual classes facilitate the learning process in the same manner when compared to face-to-face classes."

Agree Disagree

\section{Virtual classes and learner autonomy:}

6. "Virtual classes promote responsibility, self-awareness, and self-dependence".

Agree Disagree

7. Do you believe that it is possible to develop the four EFL skills through virtual classes?

Yes No

8. Based on your experience, do virtual classes play a significant role in making you an autonomous learner?

Yes No 
9. From your experience in learning, how does this type of class make autonomous learners?

10. In your opinion, what are the advantages and disadvantages of a virtual class?

Appendix 2. Teachers' Questionnaire

A questionnaire regarding teachers' Reflections on Their Experiences with EFL Virtual Classes.

General information:

- Age:

$$
20 \text { - } 29 \text { / } 30 \text { - } 39 \text { / } 40 \text { - } 49 \text { / 50+ }
$$

- Years of experience in teaching English:

Less than 5 years / 5 to 9 years / 10 to 20 years / More than 20 years

Teachers' perceptions:

1. Do you prefer using a virtual class in your teaching rather than a face-to-face classroom setting?

Yes No

2. What kind of attitudes do you have toward virtual classes?

Positive attitudes or Negative attitudes

3. Do you think that a virtual class can cause difficulties or problems that may handicap your teaching process?

Yes No

4. If Yes, please list significant difficulties?

5. Do you agree with statement that virtual classes facilitate the teaching process when compared to face- to-face classes?

Agree Disagree

\section{Virtual classes and learner autonomy:}

6. "Virtual classes promote responsibility, self-awareness, and self-dependence". Agree Disagree

7. Do you believe that it is possible that learners develop the four EFL skills autonomously via virtual classes? Yes No

8. Based on your experience, do virtual classes play a significant role in making learners autonomous? Yes No 


\section{Macrothink}

9. From your experience in teaching virtual classes, how does this type of class make learners autonomous?

10. In your opinion, what are the advantages and disadvantages of a virtual class?

Appendix 3. Responses

a) Teachers' responses:

1. Do you prefer using a virtual class in your teaching rather than a face-to-face classroom setting?

20 responses

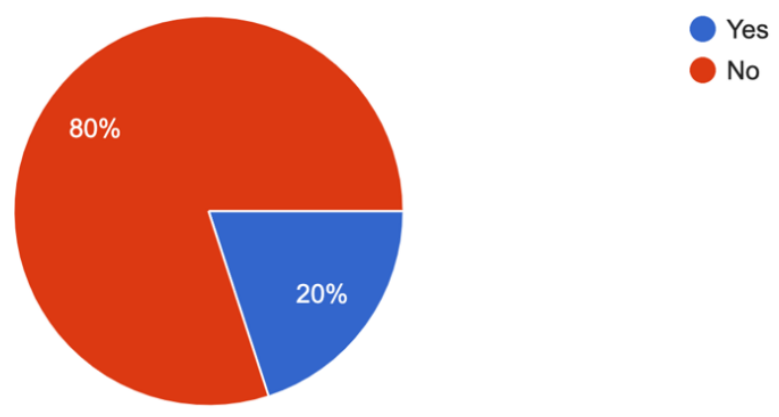

2. What kind of attitudes do you have towards virtual classes?

20 responses

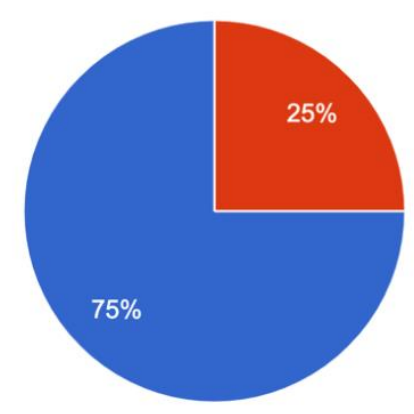

Positive attitude

Negative attitude 
3. Do you think that a virtual class can cause difficulties or problems that may handicap your teaching process?

20 responses

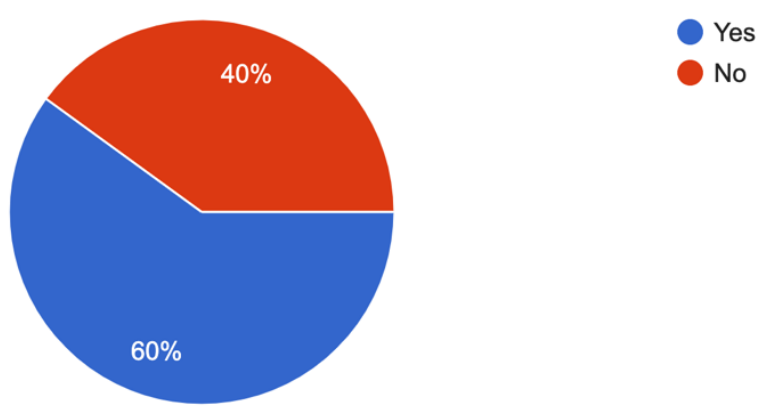

5. Do you agree with the statement that virtual classes facilitate the teaching process when compared to face- to-face classes?

20 responses

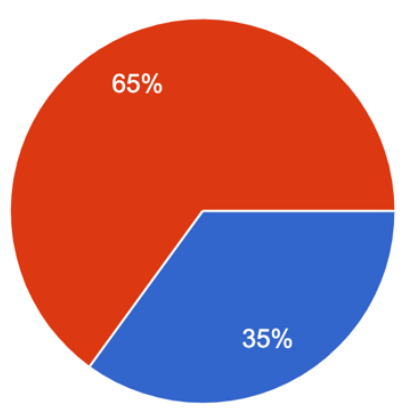

Agree

Disagree

6. Virtual classes promote responsibility, self-awareness, and self-dependence".

20 responses

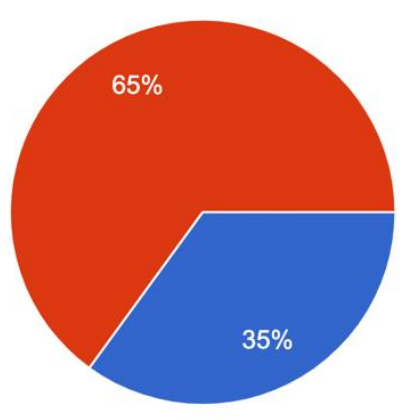

Agree

Disagree 
7. Do you believe that it is possible for learners to develop the four EFL skills through virtual classes autonomously?

20 responses

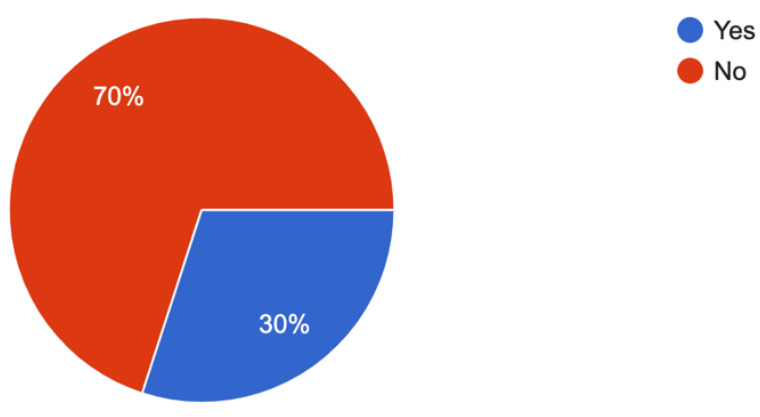

8. Based on your experience, do virtual classes play a significant role in making learners autonomous?

20 responses

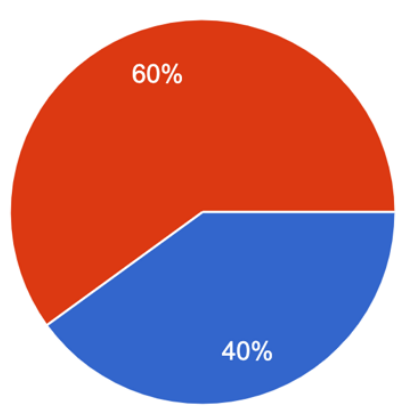

Yes

No

b) Students' response: 
ا ـ هل تفضلين تعلم اللغة الإنجليزية باستخدام الفصول الافتر اضية عوضًا عن الفصول الدر اسية وجهًا لوجه؟

22 responses

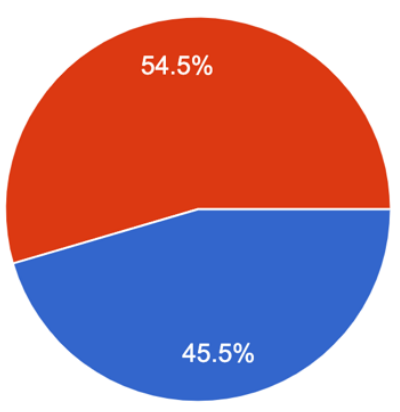

نا

r. ما هو موققاك بشكل عام اتجاه الفصول الافتر اضية؟

22 responses

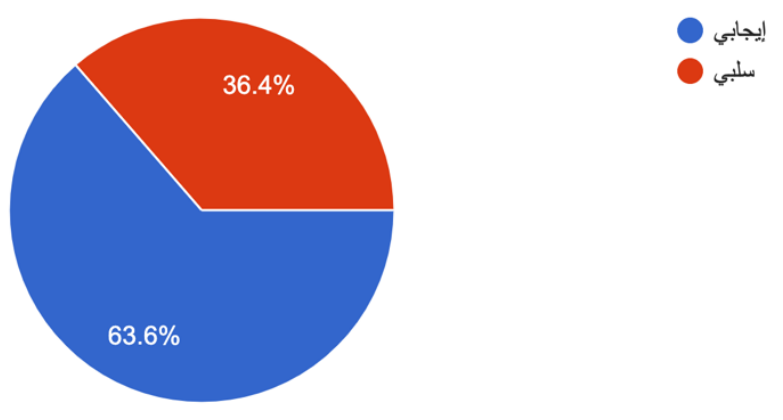

r. هل تعثقدين أن استخدام الفصول الافتر اضية يمكن أن يسبب صعوبات أو مشاكل قد تعوق عملية التعلم الخاصة بك؟ 22 responses

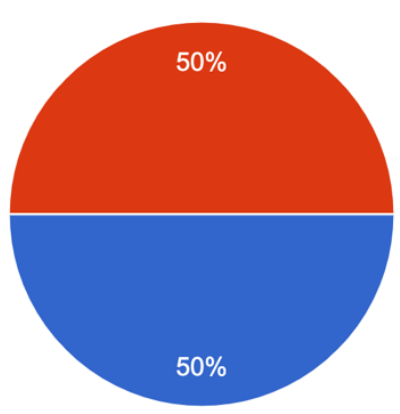

لا نامع 
"ه. "الفصول الافتر اضية تُشهل عملية التعلم بنفس الطريقة عند مقارنتها بالفصول الدر اسية وجهًا لوجها.

22 responses

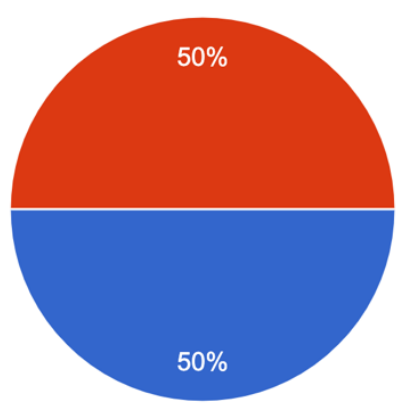

$$
\text { لا أوافق }
$$

"7. "تعزز الفصول الافتراضية المسؤولية والوعي بالذات والاعنماد على الذات.

22 responses

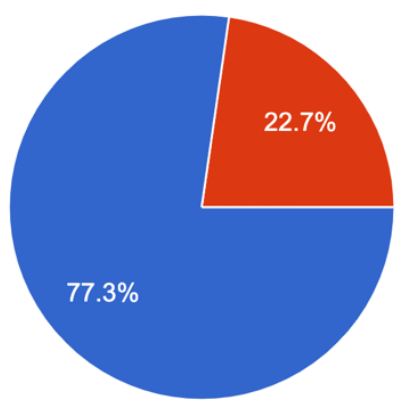

$$
\text { لا أو اففق }
$$

V. هل تعثقدين أنه من الممكن تطوير مهار ات اللغة الإنجليزية الأربعة (الكتابة، القراءة، التحدث، والاستماع) من خلال الفصول الافتر اضية؟ 22 responses

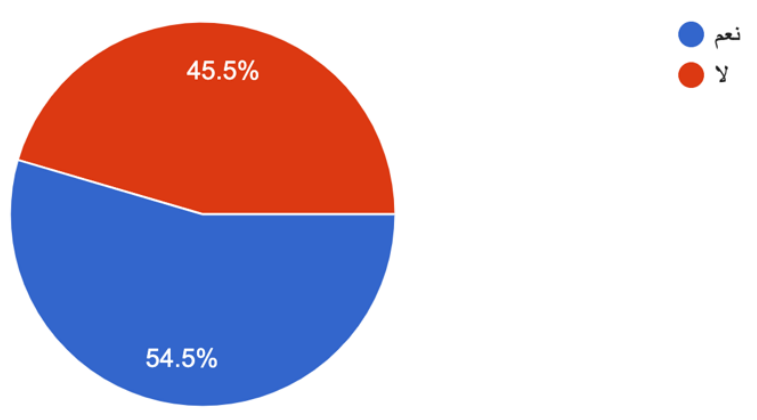




\section{Macrothink

^. هل تعثقدين أن الفصول الافتر اضية تلعب دورًا مهمًا في جعلك منعلمًا مستقلاً بذاتك دون الاعتماد على المعلمة؟

22 responses

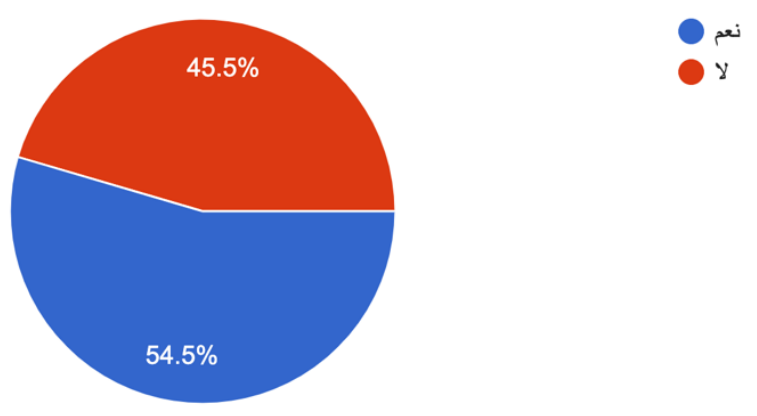

\section{Copyright Disclaimer}

Copyright for this article is retained by the author(s), with first publication rights granted to the journal.

This is an open-access article distributed under the terms and conditions of the Creative Commons Attribution license (http://creativecommons.org/licenses/by/3.0/). 